\title{
Comparative organoleptic examination of apple varieties developed by different environmentally safe technologies
}

\author{
Dremák, P. \\ Centre of Agricultural Sciences, University of Debrecen 138 Böszörményi St., 4032 Debrecen, Hungary
}

\begin{abstract}
Summary: Ecological or biological growing techniques are generally recognised as actual trends in agricultural production. The objective of our experiments is a comparison of apple fruits grown alternatively by integrated versus ecological technology. In a collection of varieties, the possibility of the experiment was feasible. At the same time, a comparison of the popularity of existing varieties was also actual. The organoleptic consumer's tests rated the varieties, and the comparison with instrumentally raised "objective" data could be compared with the subjective ratings, which did not coincide with each other. This phenomenon was revealed in the rating of acid-sugar harmony, where the internationally used quality index of Thiault produced a different range of the samples then the consumer's test. The same contradiction was observed between ratings of firmness and the data raised by penetrometer.
\end{abstract}

Key words: organileptic, apple, consumer choice, sugar, acid

\section{Introduction}

There are substantial differences between integrated and ecological type of fruit production technologies regarding nutrition and phytosanitation technologies. Integrated technology applies synthetic chemicals occasionally (insecticides, fungicides and chemical fertilisers) for producing better quality and more copious yields, whereas the ecological or biological (bio) production is exclusively restricted to the use of materials, which occur in the nature (Gonda, 2005). The majority of consumers are already conscientious of preferring food, which was produced by environmentally proper technologies, especially by ecological or biological procedures. Cultivar preferences and Thiault index were previously studied on different apple cultivars (Thiault, 1970; Anonymous, 1993; Gonda et al., 2000; Holb et al., 2000; Tóth and Bodor, 2004)

In the present study, we aimed to answer the questions: what is the main difference between fruit produced by ecological technology compared with the fruit derived from integrated technologies. Which are the main crucial parameters observed by the consumers, eventually different from the measurements obtained in the laboratories.

\section{Materials and methods}

Comparative examinations of many years have been summarised referring to 7 apple varieties grown alternatively by integrated and by ecological technologies. Samples of fruit have been rated on the basis of organoleptic tests. The assessment was performed in October 2008 by a group of 50 students, males and females of nearly equal numbers. In each sample either integrated or ecological, was judged according to the colour of the flesh, smell, acid-sugar harmony (acidity/sweetness balance), consistency, crispiness of the skin. Characters were rated on a scale of 1-5. The appearance has not been considered because the size would have influenced the subjects. On the figures, the full columns represent the values lower than the mean, the striped ones the higher values than average.

\section{Results}

The acid-sugar harmony was an important point of decision. Results are shown in Figure 1.

From the point of view of acid-sugar harmony, the samples have been ranged on the figure. The mean being 3.12 , and the samples were divided into two groups. 'Royal Gála' has been chosen as standard, thus both samples of 'Jonagold' and 'Liberty' of bio culture were rated better even than the standard. Both technologies of 'Rewena' and 'Pilot' proved to be inferior than the mean. However, both samples of the resistant 'Remo' and 'Jonagold', as mentioned already, were members of the better group.

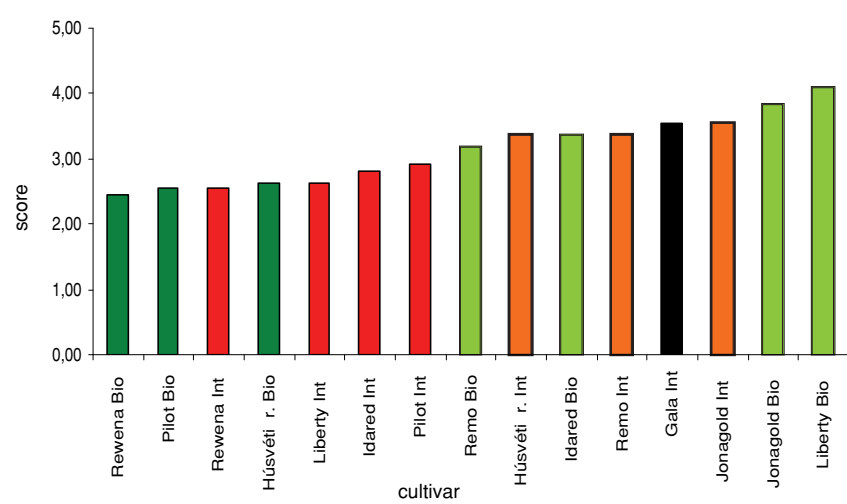

Figure 1. Evaluation of apple samples according to their acid-sugar harmony (Debrecen, 2008) 


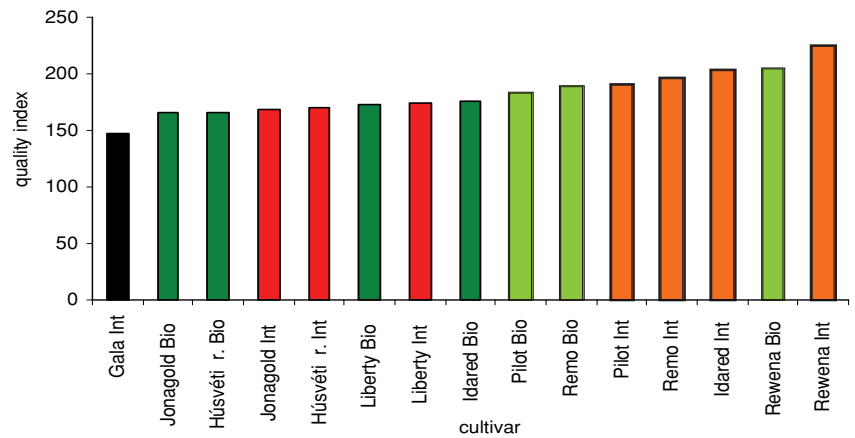

Figure 2. The range of samples according to the quality index (Debrecen, 2008)

Figure 2 shows the quality index of the samples according to Thiault.

The subjective qualification of the consumers did not coincide with internationally recognised quality index of Thiault. The index regards the ratio of acids and sugars, which could be easily measured under simple conditions. The chosen standard, 'Royal Gála' proved to be the weakest according to the measurements in spite of the consumers', who ranged the variety into the higher group. Similar tendency is observed in the case of 'Jonagold' being inferior according to the instrumental data, all the same, consumers ranged it as the best one. 'Rewena' should be considered as the best variety according to instrumental measurements, but the consumers did not like it, subjectively.

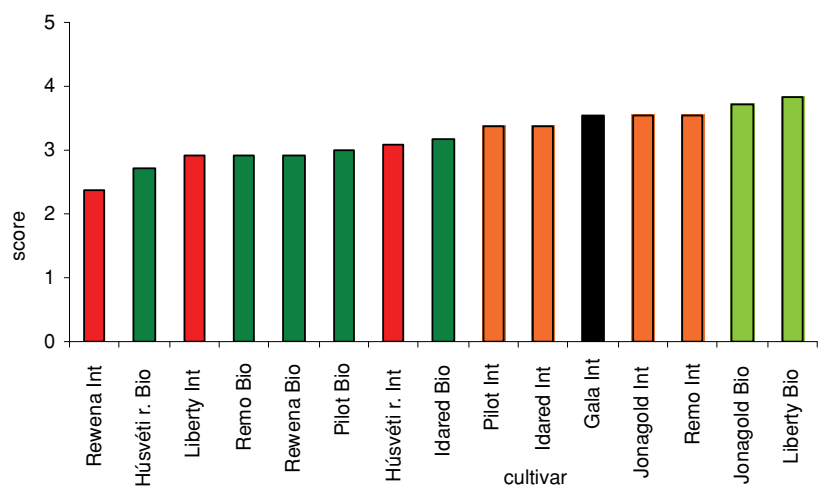

Figure 3. The range of samples rated according to flesh consistency (Debrecen, 2008)

Figure 3 shows the range of varieties according to flesh consistency. For the consumers of fresh fruit, the consistency is a decisive moment. As the subjects of the tests represented a young age-group, they preferred the crispy fruits. In this relation, the variety 'Royal Gála' fulfilled the same role as in the acid-sugar relation. Being considered as a control, it is outstripped by two samples of 'Jonagold', by bio 'Liberty' and by the integrated 'Remo'. In the lower than average group, there are over-represented the samples produced by ecological technologies because the sprays increasing the Calcium content of the fruits are not allowed.

Figure 4 shows range of samples according to the data of measurements with a penetrometer. The consumers rated the firmness of the variety 'Royal Gála', differently. Samples of integrated technology are more represented in the higher than average group. The best firmness was found in the variety 'Pilot' and in 'Húsvéti rozmaring', but it is not a surprise that

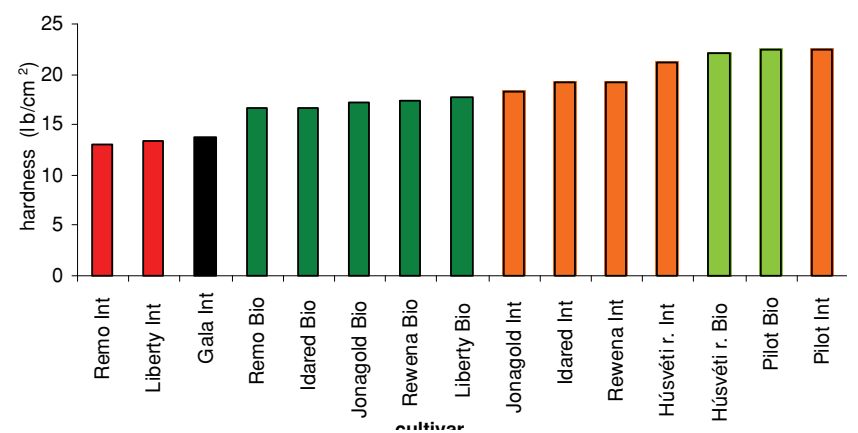

Figure 4. Range of varieties according to firmness measured (Debrecen, 2008)

'Jonagold' and 'Idared' of integrated technology are also here, as representatives of varieties for long storage.

\section{Conclusions}

In our experiment 7 apple varieties have been tested by consumers, organoleptically. Each variety was represented by two fruit samples, one grown by integrated, the other by ecological technology. As a check, the variety 'Royal Gála' has been chosen, known of its general popularity. It turned out that the individual parameters were of different importance during the process of tests. The acid-sugar ratio or "harmony" was rated differently by the subjects and by the objective data of the quality index according to Thiault. This relation is most evident in the case of 'Royal Gála' as control and the variety 'Jonagold'. The consumers, in spite of their quality index being very low, rated both favourably. Similar tendency is experienced in the rating of flesh consistency. 'Royal Gála' and both samples of 'Jonagold' received favourable ratings, in spite of the objective measurements, which did not prove their firmness. Objective data and subjective ratings as compared with each other, may contradict. It was stated that the consumers' rating is different from the objective facts not only in acid-sugar ratio, but also in the judgement of flesh firmness.

\section{References}

Anonymous (1993): Washington apple maturity program, Wenatchee, WA.98801.

Gonda, I. (2005): A klímaváltozás, valamint a gyümölcs művelési rendszerek és a termesztéstechnológiák termésbiztonsági összefüggései. „Agro 21-füzetek” Budapest, 3-21.p.

Gonda, I., Holb, I. \& Bitskey, K. (2000): Rate of scab infection and quality parameters of apple fruit in organic and integrated production systems. Int. J. Hortic. Sci, 6 (4): 63-67.

Holb, I., Kiss, Zs. \& Bitskey, K. (2000): Előzetes adatok almafajták varasodás fertőzöttségi mértékéről és a gyümölcs beltartalmi paramétereiről két környezetkímélő rendszerben. Ifjúsági Tudományos Fórum, Keszthely, CD Kiadvány, pp. 1-5.

Thiault, J. (1970): Etude de Criteres Objektifs de Qualité Gustative de Pomme Golden delicious. Cerafer Centre, Interregional, d'Aix-enProvence. Washington

Tóth, G. \& Bodor, P. (2004): Almafajták értékelése a hazai termeszthetőség és a vásárlói megítélés szempontjából. Kertgazdaság, 36 (3): 3-14.p. 